\title{
The spotlight shines on all
}

\section{ACRL's Excellence in Academic Libraries Award}

\author{
by Gloriana St. Clair
}

$\mathrm{T}$ he spotlight of the award shines not just on one individual, but on the whole group. All three winners of the newly created Excellence Award from the College of DuPage, North Carolina State University, and Wellesley College agree that this broad inclusiveness is its greatest benefit.

Librarians and staff in these three institutions do much more than their own jolss; in each case, they extend assistance to meet the special needs of their faculty, staff, students, and communities. As winners of the award, each library has received special attention from its academic community.

College of DuPage Director Bernard Fradkin noted "Trustees, administrators, and faculty often take the in-house library for granted until someone

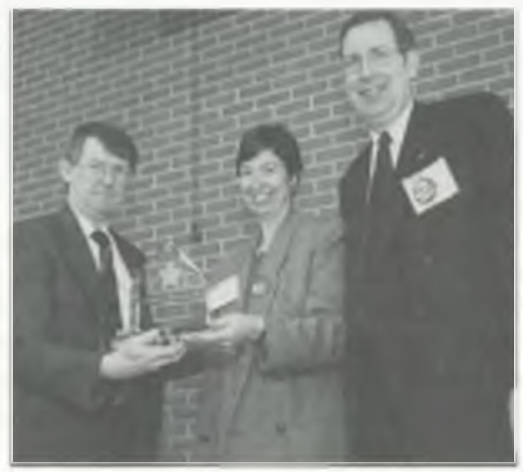

Larry Hardesty, past-president of ACRL, presents the crystal trophy to North Carolina State University's Chancellor Marye Anne Fox and Provost Kermit Hall. college crowd. Fradkin reflects, "There's nothing like peer recognition and college-wide acclamation."

As a result of winning the award, many others have asked to visit and to use the models developed at DuPage. These interactions are complimentary but also allow DuPage staff to contribute to the general advancement of all academic libraries. Fradkin hopes "that this program continues to grow and flourish, offering the opportunity of identifying additional exceptional programs that we can all learn from and model."

Micheline Jedrey, vice president for information services and college librarian at Wellesley College, commented that "faculty continue to congratulate the library on receiving the Excellence Award, more than two months after the campus celebration was held."

The crystal award sculpture is displayed prominently in the entry lobby of the Margaret Clapp Library, the main library on campus, and will be displayed in each of the

\section{About the author}

Gloriana St. Clair is university librarian at Carnegie Mellon University and chair of the Excellence in Academic Libraries Award committee, e-mail: gstclair@andrew.cmu.edu 
department libraries during the next several months.

The timing of the award was particularly fortuitous, as the college started in September a yearlong celebration of the 125th anniversary of its opening. As Jedrey states, "The key to the library was one of three keys presented at the first formal inauguration of the college president, signifying the importance of the library to the intellectual vitality of the institution.

The Fxcellence Award is a tribute to Wellesley's enduring commitment to provide outstanding library resources to the college community.

At North Carolina State University (NCSU), Chancellor Marye Anne Fox announced that she would have the NCSU Memorial Belltower lighted in red that evening, a signal honor for major awards and athletic victories at the university. Fox and Provost Kermit L. Hall expressed their pricle in the library staff's accomplishments and commented on the continuing importance of academic libraries to major research institutions. The Raleigh newspaper published an editorial praising the libraries and encouraging the university to continue to sustain its momentum.

NCSU Libraries hosted an elegant luncheon before the event and handed out gold-plated commemorative bookmarks, while ACRL supplied red buttons that read "NCSU Libraries:
Best of the Best." ACRL Past-President Larry Hardesty, who attended the ceremony, noted, "It is a great to honor our library colleagues as they come together as a team to support the mission of their institution further."

Institutional homepages provide further insights into the gloriousness of the award ceremonies at these three campuses. ${ }^{1}$ There, photos of the awards ceremonies-with quotes from the presidents and honored guests who attended-indicate the richness and diversity of the celebrations.

Hardesty, who conceived the award and convinced Blackwell to sponsor it, continues to muse on the worthiness of these institutions and the generosity of Blackwell's in making the award possible. "I am pleased that Blackwell's Book Services, a family-owned business with an outstanding reputation among academic librarians, has chosen to sponsor the award honoring excellence among academic libraries."

Hardesty said that to have these libraries receiving the recognition they deserve from their campuses surpassed his expectations in creating the award. "We are honoring the right team-the library team!" he said.

\section{Note}

1. See www.wellesley.edu/Library/award/ award.html.

\section{Nominate your library for the ACRL Excellence Award}

The 2000/2001 nominations committee members are busily seeking applicants for this year's award. Libraries may contact any of these individuals or may nominate thenselves:

- Lynnette Anderson (lynnand@acacl. (c.whecn.edu) edu)

- Will Bridegam (webridegam@amherst.

- William J. Crowe (wcrowe@ukans.edu)

- Evelyn Minick (minick@sju.edu)

- Gloriana St. Clair (gstclair@andrew. cmu.eclu)

The guidelines for the Excellence Award are available at http://www.ala.org/acrl/ guidelines.html. The three award-winning applications can be viewed at http:// www.ala.org/acrl/exclnce.html.

In reflecting on the selection process, the Excellence Award Selections Commit- tee noted how important it was for the library to tell the story of its interactions with the campus in a cohesive and compelling manner. Few committee members had time to review additional materials that accompanied the application. The Excellence Awards focus on teamwork and campus interactions in service of educational mission tended to outshine specific projects. The 2000/2001 Selections Committee includes Maureen Sullivan, Larry Hardesty, Debra Gilchrist, Robert Wedgeworth, and Damon Hickey,

The committee seeks a pool of applicants to make the $2000 / 2001$ decisions just as difficult as those in 1999/2000 were. The spotlight is preparing to shine on another group of equally worthy excellent academic libraries. 